\title{
Soqotra's pastoral economy: from core to auxiliary livelihood
}

Serge D Elie

\begin{abstract}
This article describes the current functioning of the pastoral economy of Soqotra Island, a sub-national entity of the Republic of Yemen on the Arabian Peninsula, located in the Indian Ocean at the entrance of the Red Sea. Soqotra's contemporary pastoral economy is the legacy of a transition process engendered by a state-initiated disarticulation from the subsistence economy of the hinterland with the political economy of the state. This process transformed the practice of pastoralism in Sogotra from a core economy to an auxiliary livelihood. The introductory section offers an historical synopsis of this disarticulation process through a description of the political economy of four mainland-imposed regimes on the island. The second section undertakes a brief explication of the mistaken identification of Soqotran pastoralists as bedouins. Subsequently, the article details the workings of pastoralism as an auxiliary livelihood through an analytical description of the three key spheres of activity in any system of livelihood: production, distribution and consumption. Finally, it briefly explores the sustainability of pastoralism in Soqotra by considering future scenarios about its prospects on the island.
\end{abstract}

Keywords: Core economy; Disarticulation; Generational shift; Political economy; Resilience; Subsistence; Yemen

\section{Introduction: pastoralism on the wane}

The fate of Soqotra's pastoral economy mirrors the historical trajectory of pastoralism at the global level: from a dominant geopolitical system to a subsidiary economic activity under the tutelage of other political-economic regimes. The practice of pastoralism is millennia-old in Soqotra, but it seemed to have reached its apogee between the 1890s when the seat of power of the Sultanate of Mahra on the mainland shifted to Soqotra under British tutelage and until the 1967 revolution in South Yemen brought about the end of the Sultanate (Elie 2008). During this period, pastoralism constituted the 'core economy' as it encompassed the totality of primary socio-cultural and political-economic institutions and related activities, which revolved around attending to the needs of the pastoral herds. These activities were dedicated to the survival and reproduction of pastoralism as a communal way of life. The overwhelming majority of the island's inhabitants were active contributors to the perpetuation of pastoralism through the intergenerational transfer of its knowledge repertoire, which constituted the ensemble of

Correspondence: jds_elie@yahoo.com

Yemen Center for Studies and Research, P.O. Box 7305, Sanaa, Yemen socio-cultural practices that sustained the community and ensured its continuity.

Soqotra's pastoralism was based on the production of milk and its conversion into a series of milk-related products, but especially of butter oil (hami in Soqotri), which was used as an inter-regional trade product. However, this emphasis on milk production and its conversion into butter oil as the main economic objective of animal husbandry in Soqotra was not the result of specialization for local exchange, although that played a role, but more importantly, it was an export-driven production that was primarily motivated by the political economy imperatives (i.e., institution-maintaining and revenue generation needs) of the Sultanate, and secondarily by the subsistence necessity of the pastoralists who used butter oil as a bartering currency in local and trans-local exchanges to procure the essential food items and other basic goods not available in the pastoral domain.

In effect, the production of butter oil by pastoralist households throughout Soqotra's hinterland was integral to a dialectical symbiosis between the subsistence economy of the hinterland and the political and economic interests of the Sultanate's coastal elites. This symbiosis was achieved through a particular taxation regime that 
can be described, in Earle's (2002) term, as 'staple finance', which acted as a coercive production incentive in a non-cash economy: It refers to a strategy of mobilizing 'food items and their local vertical transfer to an elite segment of the polity' who used them as currency to procure the services it needs (2002:84). Accordingly, the centrality of pastoralism throughout the Sultanate period was due to its full incorporation as the primary source of 'staple finance' that maintained the Sultanate's institutions (for historical details, see Elie 2009). The explanatory, or theoretical, ramification of the role of 'staple finance' as a taxation regime is that, at least in the case of Soqotra, it challenges, as well as offers a contrary narrative to, the conventional thesis that pastoralism is axiomatically a political strategy of self-determination employed by pastoralists for resisting state encapsulation or domination (Chatty 2006; Khazanov 1994). Instead, the shifting fortunes of pastoralism in Soqotra can best be understood as resulting from the disarticulation of the subsistence economy of the hinterland, that is the 'ways that households are maintained through everyday activities'; from the political economy imperatives of the state, which 'involve the ways in which surpluses are mobilized to support political activities, lifestyle, and institutional operations of an elite segment' of society (Earle 2002: 83-4). Indeed, since the Sultanate's demise, Soqotran pastoralists did not have to resist the state as it was chronically absent in their pastoral domain, but the pastoralists sought to participate opportunistically in the territorially adjacent state-sponsored economy on the coast to sustain their pastoral economy. This emergent urban-oriented, coastal-based and state-managed political economy was driven by the modernizing nationbuilding imperatives of the new state, which entails, among other tasks, (a) the recruitment of institutional cadres for the local governance of a communal polity information, and (b) the preparation of a productive labour force for a modernizing economy. Hence, the Yemeni state's selective promotion of political-economic agents from the hinterland who could be instrumental to its statebuilding objectives.

The state's disarticulation with the hinterland subsistence regime and its selective conscription of the rural population as its political-economic agents resulted in a serial delinking process between pastoralism as the island's once core economy and the mainland-imposed political-economic regimes. This delinking, or disarticulation, process can be illustrated through a brief overview of the political-economic regimes on the island under four different historical periods. This process confirms that Soqotrans' historical experience is one in which their mode of livelihood was always appropriated into an externally imposed dominant political economy (see Heatherington 2001 for a comparative case; Galvin
2009). The summary of these four political-economic regimes is offered as background to the discussion of the current pastoral economy as auxiliary livelihood: (a) a tributary regime, under the clan-based feudalism of the Sultanate (1490-1967), which depended on maximizing surplus extraction on all productive and trading activities of the population, and whose preferred economic agent was a pastoralist confined to the hinterland herding livestock and producing butter oil. (b) A distributive regime, under the socialist administration (1967-1990), which emphasized egalitarian current consumption that was introduced through forced modernization, and encouraged, if not coerced, part of the population of Soqotran pastoralists into a population transfer towards coastal and into urban-based occupations either as fishers and administrative cadres. (c) A developmental regime, although nominally so, fashioned by the unity government (1990-1996), which promoted marginal social and economic change while enhancing the potential for social tensions due to the differentiation in access and opportunities based on the state's recruitment of Soqotrans as competing tribesmen into a patronage system. And (d) a conservationist regime (1996 to the present), in which the state exercises shared sovereignty over the island with international agencies that are promoting the development of a service economy partly driven by an environmental protection and ecotourism sector in which Soqotran pastoralists and non-pastoralists are encouraged to participate as environmentally conscious and economically opportunistic individual actors.

The cumulative impact of this succession of politicaleconomic regimes and their disarticulation from the hinterland's pastoral economy is the demise of pastoralism from its status as a core economy and its marginalization into an auxiliary livelihood. The latter is increasingly affected by the phenomenon of discontinuity in the inter-generational transfer of pastoralism's accumulated knowledge repertoire and the associated socio-ecological praxes. The end result is the accelerated shedding of Soqotran pastoralists' cultural legacy and livelihood traditions while they remain uncertain about the viability of the proposed alternatives.

The remainder of the article is organized as follows: the next section clarifies the origin of the confusing designation of the Soqotran pastoralist as a bedouin and the nature of his economic agency. The subsequent section describes the current functioning of pastoralism as a parallel economy in relation to an emergent urban-based economy. This is done in terms of the productiondistribution-consumption nexus, which encompasses the spheres of activity crucial to the social reproduction of a way of life. The last section considers the future prospects of pastoralism in Soqotra. 


\section{Soqotran pastoralists: mistaken identity and marginalized agency}

Historically, the pastoralists in Soqotra were always regarded as a social category entirely outside the pale of urban life, as they represented a socially undifferentiated mass separated geographically from the other social groups on the coast. As recently as 1967, they were still being described as 'timid troglodytes' (Doe 1992:31), as they inhabitated mountain caves and shelters made out of rubble on the plains. Their interaction with coastal settlements, or their representatives, was the most furtive, occasioned only by the need to procure items related to their existential necessities: barter of butter oil for imported items from the Arab merchants, and the reciprocal exchange of a basket of goods with coastal residents as part of a system of mutual assistance for survival (mahrif), or the payment of taxes to the Sultan's tax collectors. They were the pillars of the Sultanate's rent extraction regime, as they were the main tax payers in its tribute-dependent economy. They were the primary producers of butter oil, which was the main export item and thus the 'foreign exchange' earning commodity on the island. Yet, economically, they were less well positioned in terms of access to the prized food items (e.g., maqdere (maize), dates, etc.).

While Soqotran pastoralists are not nomadic bedouins, it is the Arabic term badī (badawi sing.) that was, and is still being, used locally to refer to them - although more as a cultural epithet than as an occupational description. The term $b a d \bar{u}$, however, is not originally an indigenous collective self-reference, but an externally imposed designation on the inhabitants of Soqotra's hinterland. It seemed to have been borrowed from the established lexicon of the Arabian Peninsula, where the word was always associated with residents of the desert fringe or the hinterland separated from the urban or coastal settlements. In the case of Soqotra, the Mahri tribes who occupied the island were from the coast, and thus their use of badū to designate Soqotra's mountain dwellers was a conceptual transfer of the term used about Mahra's hinterland inhabitants who were truly badū (i.e., nomadic pastoralists).

Paradoxically, there seems to be no common designation in the Soqoți language for the word pastoralist. The word that is used for pastoralist denotes an activity and not an identity is re'hi (plural re'hiyitin), which means one who looks after livestock (personal communication with Dr. Miranda Morris). Worthy of note is the fact that today the term badi is not used in official government documents (decrees or reports), but pastoralists $r a^{\prime} a h$ ( $r a^{\prime} y$ sing. in Arabic) as an occupational designation. In fact, the inhabitants who were called badi by outsiders were locally known as saqați, a term that was originally an ecologically mediated and geographically bounded identity and which referred exclusively to the residents in the isolated mountainous habitats in the central and western parts of the island, who were non-fish-eating, non-agriculturalist, non-camel/donkey-owning and who were primarily sheep and goat herders. In contrast, the inhabitants in the rest of the island's hinterland did not have a collective self-reference but referred to themselves by their individual clan or territorial names.

Beyond their mistaken identity, in terms of economic agency, the Soqotran pastoralists have always made up the majority of the population enduring the hinterland's austere living conditions, as if in a state of permanent socio-economic orphanage from external assistance, a situation that persists today. The economic exploitation of pastoralists during the Sultanate has mutated into a benign economic neglect from the political authorities at the local and national levels. Today, the pastoralists are the least integrated in the cash economy. This is partly due to a tradition of strong attachment to their lifestyle as well as a chronic absence of, or delayed and inadequate, interventions (e.g., schools, or employment generation schemes) in their territorial domain by governmental agencies until recently. The end result is the rise of a peculiar cultural-economic category, namely the transitional pastoralist, drawn by the pull of the cash economy of the town into the calling of an itinerant odd-jobber and driven by the push of an increasingly uneconomic pastoralist livelihood due to the vagaries of the environment and the seasonally constrained local market, and the lack of export opportunities for their livestock. Yet the pastoralist is unable to abandon one for the other, as both occupations are subject to the seasonal variability of economic opportunities on the island.

\section{The ethic of 'patching-up': workings of an auxiliary livelihood}

The parallel economy refers to the pastoral economy of the hinterland that has yet to be, or may not be, integrated into the emerging non-traditional economic sector. Paradoxically, rural Soqotrans who were not nomadic seem to have become nomadic, or at least compulsively peripatetic, in their manic attempts to make ends meet in the current economic context. This is partly an imposition of the seasonal rhythm that economic activities on the island must inexorably mimic, but it is also a need created by dependence on non-pastoral food items and the ripple effects of the increasing monetization of the rural economy. Accordingly, rural Soqotrans whatever their ecological niches or primary means of livelihood are, by necessity, multiple livelihood pursuers animated by a chronic economic opportunism in quest of cash. This opportunistic pursuit takes the form of a kind of economic vagrancy compelled by the intrinsic insufficiencies of their subsistence livelihoods, caused by environmental conditions as 
well as an economic situation describable in the nomenclature of scarcity: a chronic precariousness of environmental resources (e.g., water and pasture), and seasonally variable exchange rate between pastoral by-products and the food basket made up almost entirely of imported items. The only available recourse is to be on the constant lookout for remunerative activities (e.g., odd jobs especially in the construction boom in Hadiboh town) that depend on the seasonal cycle.

Since the end of the Socialist period, nature's rhythm seems to have been thrown out of kilter. Seasons come and go without bringing the expected rains, resulting into a chronic depression in the ecosystem's productivity in terms of environmental resources (Scholte and De Geest 2010). Soqotrans have interpreted this situation to be the end of baraka (God's blessing). Consequently, the natural symbiosis between rain, grass and milk that constituted, at least metaphorically, a 'virtuous cycle' of production and consumption within the pastoral domain has come to an end. This signalled the dawning of hamshal, which is a Soqotri word indicating the withdrawal of God's favour (baraka), and thus the onset of poor productivity of the island's natural resources (Morris 2002:500). This has created a social disposition characterized by an obsessive self-reliance through a creative coping with the deficiencies of the pastoral economy, in the absence or inadequacy, of any kind of support from the state, or the short-term and whimsical attention from international agencies. The local concept for this disposition is iraqqa which means 'patching-up', and it is a metaphoric reference to the miscellany of odd jobs that pastoralists must seek out to make ends meet and complemented by the mutual aid customs (see Elie 2006: chapter 5). The term is Arabic, but Soqotrans have appropriated it for their own metaphoric deployment: it refers to patching up a punctured tyre, as part of the continuous maintenance of that one wheel of life, in the absence of a spare, so that it can keep turning. In fact, iraqqa was the way a pastoralist described his way of making a living in an exasperated tone, after a series of questions that sought to reduce his way of life to monthly budget figures. He momentarily abandoned the restraining decorum when addressing a stranger, as he confided, 'If we were not ashamed we would go begging sometimes'. In effect, 'patching up' is the only viable strategy to deal with the contextual contingencies generated by the environmental uncertainties and resource insufficiencies (natural and financial) that structure the quotidian existence of Soqotran pastoralists. In fact, raqqa al-ḥayāh ('patching up life') is almost an automatic refrain among pastoralists in discussion about making a living in the bädiya (hinterland).

The preponderant feature of this traditional pastoral economy is the mutually reinforcing symbiosis between the norms of sufficiency and the absence of an accumulative logic, or more generally the lack of a culture of stored wealth. There is no conception of savings, or even the possibility for accumulation to palliate the inevitable vagaries of the coming season. The one exception is the storage of 25- to $50 \mathrm{~kg}$ bags of rice, flour and sugar imported from the mainland and the Emirates. The acquisition of these items is the main justification of any productive and exchange activity. There seems to be no concept of a surplus-generating economy. For the Soqotran pastoralists, the herd is not seen in terms of exchange values but in terms of subsistence security (e.g., milk production for household consumption exclusively, and animals are for occasional, and indeed reluctant, sale to make ends meet). This symbiosis is the equivalent of the Soqotran 'pastoral rationality', which is expressed in the scattered individual economic behaviours in which subsistence prevails over maximization of benefits, and that constitutes a way of life as well as a system of production. However, this notion of pastoral rationality would perhaps be adequate to a community of dedicated pastoralists whose social reproduction system has remained impervious to the economic changes in the larger context in which it operates. In contrast, Soqotran pastoralists are straddling a transitional threshold, as their pastoral economy seems caught in a state of suspension between a hinterland as a pre-capitalist social formation and the urbanizing northern coast, primarily Hadiboh town, as a proto-capitalist periphery of the mainland's economy. Therefore, what is pastoral rationality elsewhere is experienced as an inexorable, if not burdensome, adaptation imperative to the environment's whims and the demands of the ever widening monetized exchange circuit. Accordingly, Soqotra's traditional economic sector can be seen either as operating within the bounds of a virtuous circle inspired by an environmentally conscious ethic of frugality, or caught within an infernal impasse of a permanently delayed gratification. The first interpretation of the traditional economic sector might reflect the sentiment of an older generation of Soqotran pastoralists in the central and western regions, while symbolizing the UN's eco-conservationist fantasy. The second reflects the realism of the emerging generation of disillusioned rural Soqotrans who have been exposed to the conveniences of urban life. This exposure has induced a gradual change in consumption desires and expectations regarding standards of living.

This rural economy will be discussed using the conventional tripartite division of an economic system: production, distribution and consumption (see Gudeman 2001). However, the concept of economic system in Soqotra is problematic given the absence of a market mechanism to integrate the internal articulation between these three constitutive components. Soqotra's economy can be divided into two spatially delimited domains of economic activity with minimal overlapping spheres: the first domain, the 
rural economy, encompasses the subsistence activities in the hinterland, which is the geographically preponderant part of the island where needs satisfaction is the dominant value orientation, and is characterized by the absence of market-oriented production. The second domain, the urban economy, encompasses the coastal strips of the island especially the north where the only market place (i.e., Hadiboh town) is located - and constitutes the only domain where market-dependent economic activity takes place (e.g., fishing) and where the exchange of commodities for a profit is the dominant value orientation. The discussion below is concerned primarily with the traditional or rural sector of Soqotra's economy, which represents the livelihood infrastructure of a significant proportion, if not a majority, of Soqotrans and that has persisted - although in successively modified form - under the different political regimes and their economic policies as summarized in the introduction. This rural economic sector is descriptively analysed in terms of three dimensions: (a) production, which entails an artisanal 'mode of use' of local resources; (b) distribution, which is underpinned by a subsistence ethic that constrains production for market exchange and thus restrains the market supply of pastoral products, and (c) consumption, which is characterized by a frugality that is tantamount to a situation of chronic nutritional insufficiency. Noteworthy is that the production-distributionconsumption nexus encompasses the three key phases in the social reproduction cycle of any livelihood system, and their vagaries provide a barometer of the sustainability of pastoralism in Soqotra in the long-term.

\section{Production: artisanal bricolage}

All of the island's core livelihood activities (e.g., herding, date palm tree cultivation, etc.) that constitute production are subsistence-oriented and are guided by the "norms of sufficiency'. The latter term refers to a situation where the 'level of effort is regulated to suit the desired level of satisfaction, and the latter is brought in line with the level of effort people are willing to make' (Gorz 1993: 61). Accordingly, production does not entail formal organization of productive labour beyond the household level. Soqotrans seems merely to strategically harness their environment's providential whims, as nature assumes almost entirely the burden of production. The notion of 'mode of production' cannot be used to explain the nature of traditional economic activity on the island. Perhaps 'mode of use' of the island's environmental resources might be more applicable. There is no consistently organized production that is aimed at a local or external market, with the exception of fishing, which is not an economic activity within the pastoral domain proper, although it is performed by pastoralists.

The local production performed by Soqotrans is restricted to the following activities: handicrafts (e.g., rugs, pottery and dry palm leaves by-products) for local use and for occasional sale to the increasing number of tourists; seasonal home gardens' production of vegetables with tomato being the main cash crop as it constitutes over half of the vegetables planted in these gardens, especially in the vicinity of Hadiboh (see Ceccolini 2002), and fruits (e.g., banana, papaya, lemon and melon), in addition to tamarind and wild oranges, which are sold in the local market in Hadiboh; and collection of aloe juice and resin from the Dragon's Blood tree for the occasional shipment to the mainland and the Gulf countries. Intriguingly, it appears that the production of butter oil from cows and goats, although at low volume, has been revived as 1 litre bottles were being sold in Hadiboh during the 2013 sereb season (October to February), after a long absence (Figure 1). Perhaps, this suggests the increasing responsiveness of pastoralists to the monetization exigencies of the economy and the corollary quest to expand their income-generating activities. All of these productive activities are exclusively household-based and conducted by women.

There is an emergent auxiliary activity undertaken by an increasing number of pastoralists, namely beekeeping. The occasional activity of collecting wild honey from beehives in the trunk of trees, but more commonly caves and holes in cliff faces, by using fire to drive away the bees - and which not only destroyed the beehive but also contaminated the honey with a burned aftertaste - has been transformed into the organized production of honey, since the launching of a beekeeping project by a French NGO in 2004. In contrast to most, if not all, micro-scale projects undertaken on the island, which are abandoned once the external funding faucet is turned off, beekeeping has scaled up from an externally assisted pilot project that trained an initial 350 beekeepers, to a locally managed economic activity in which are engaged literally thousands of pastoralists in hundreds of villages throughout the hinterland. The numbers of beekeepers as well as the number of villages where beehives are kept are too numerous for an exact count, but the rough figure is that between one and three thousand pastoralists are engaged in honey production, according to the former local project coordinator. The latter is now the owner of the island's main honey shop (Soqotra Honey Center), which is the only shop with quality insurance equipment. Also, it is the primary, but not sole, purchasing agent of the honey produced on the island, as the owner guarantees a minimum price $(6,500$ to $7,000 \mathrm{YR}$ or USD 32) per litre, which is much higher than the average price of a goat or sheep. A litre of honey is normally sold at 8,000 YR, so most non-honey producing Soqotrans are priced out of the market. Nevertheless, they buy honey as an obligatory gift item when visiting acquaintances outside the island and not to consume it themselves; hence, honey is sold mainly to foreign visitors and for 


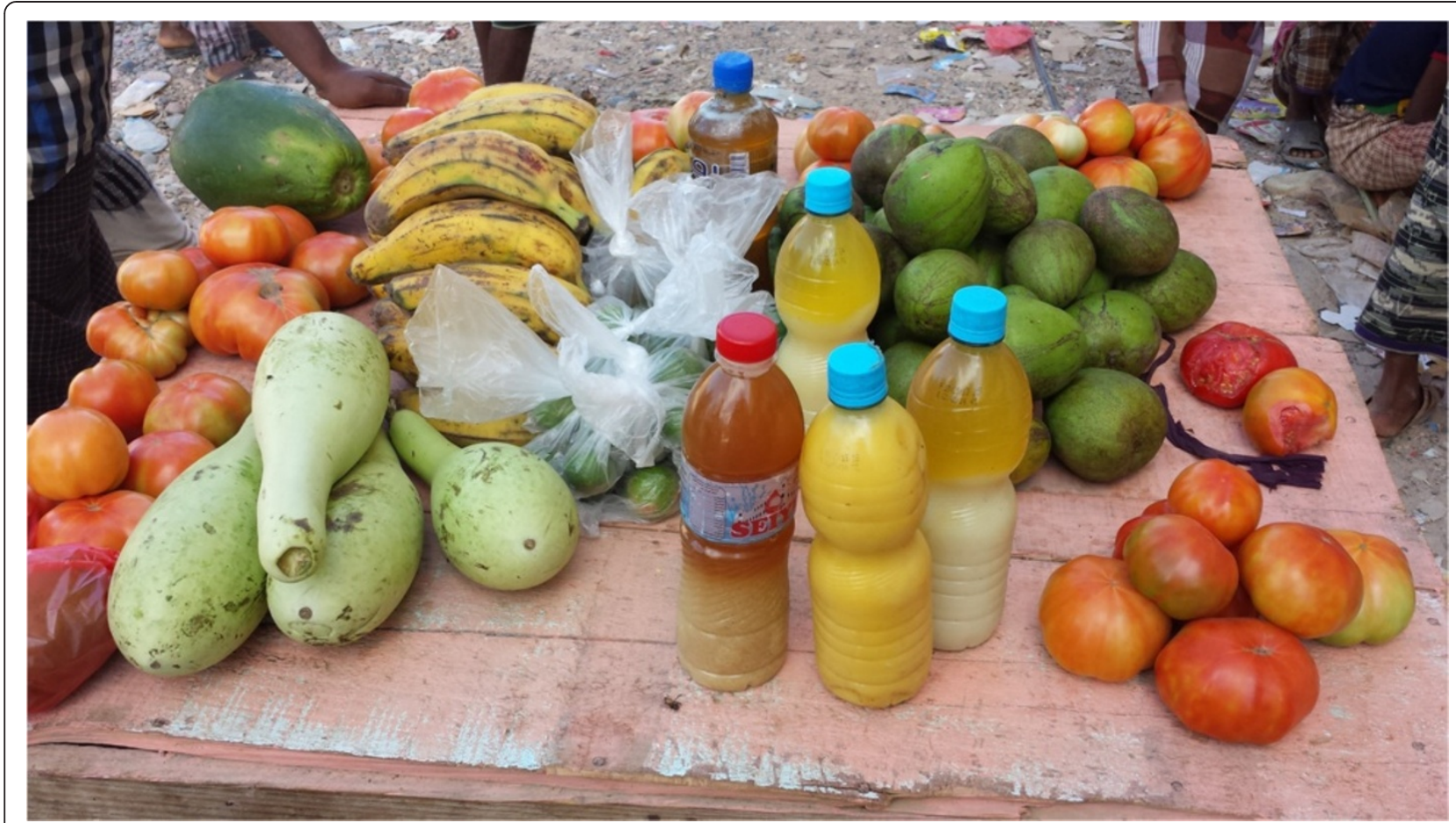

Figure 1 Products from the pastoral domain (2013).

export to the mainland. Each beehive can produce $7 \mathrm{~kg}$ per season depending on environmental conditions (Figure 2).

The end result is that beekeeping is emerging as the new cash crop of the pastoral economy as butter oil was in the past. Honey production is the hinterland equivalent of fishing on the coast. Data on the total production of honey are not readily available, but the amount of honey purchased by one shop, out a total of four shops, for the two seasons - of July to September 2013 and November 2013 to February 2014 - was equivalent to 2.25 tonnes for a monetary value of $14,625,000$ YR (USD 68,023) to $17,500,000$ YR (USD $81,395)$. The main honey production areas are in the interior valleys of the central region (shi'ib di Ilofi, and di Alf) and the interior plains of the western region (Qabhitin and Mayha). According to the owner of the main honey shop, the amount that could be earned per year by a beekeeper from properly kept beehives ranges from 520,000 to 700,000 YR (or USD 2,400 to 3,250), which is equivalent to the average yearly salary of a government employee. Moreover, this amount is over twice Yemen's gross national income (GNI) per capita, which was USD 1,270 for 2012. While these figures seem rather high, they merely indicate the potential income that can be generated if production conditions are optimal. Paradoxically, beekeeping may well become a substitute for animal selling, given Soqotran pastoralists' inherent reluctance to part with their animals, and thus would prefer to use money from the sale of honey among other incomegenerating activities to maintain their herds (see below). There are many examples of pastoralists who have measurably improved their living conditions or to have fulfilled some of their aspirations due to honey production: For example, built a new house, went on a pilgrimage to Mecca, sent kids to school, settled in Hadiboh town from the rural areas, etc. In effect, honey production is emerging as a core activity among a large and increasing number of pastoralists, and thus further relegating the economic value of the herds.

Paradoxically, the animals, which have always constituted the plurality of the island's inhabitants - estimated livestock population of over 566,000, with a human population of over 44,000 (see Elie 2014b) - and represented the foundation of the communal economy, have never been the objects of production for an external market. In fact, the primary aim of pastoralism in Soqotra - with its complex system of livestock management encompassing the repertoire of know-how of animal husbandry, which initially motivated Soqotrans' acquisition and accumulation of an encyclopaedic compendium of ethno-botanical knowledge about the island's environmental resources (see Miller and Morris 2004) - is solely dedicated to the maximization of milk production. For example, 'breeding females constitute the main age and sex group for all ruminant species... [which] ensure that the conversion of available range vegetation to milk is 


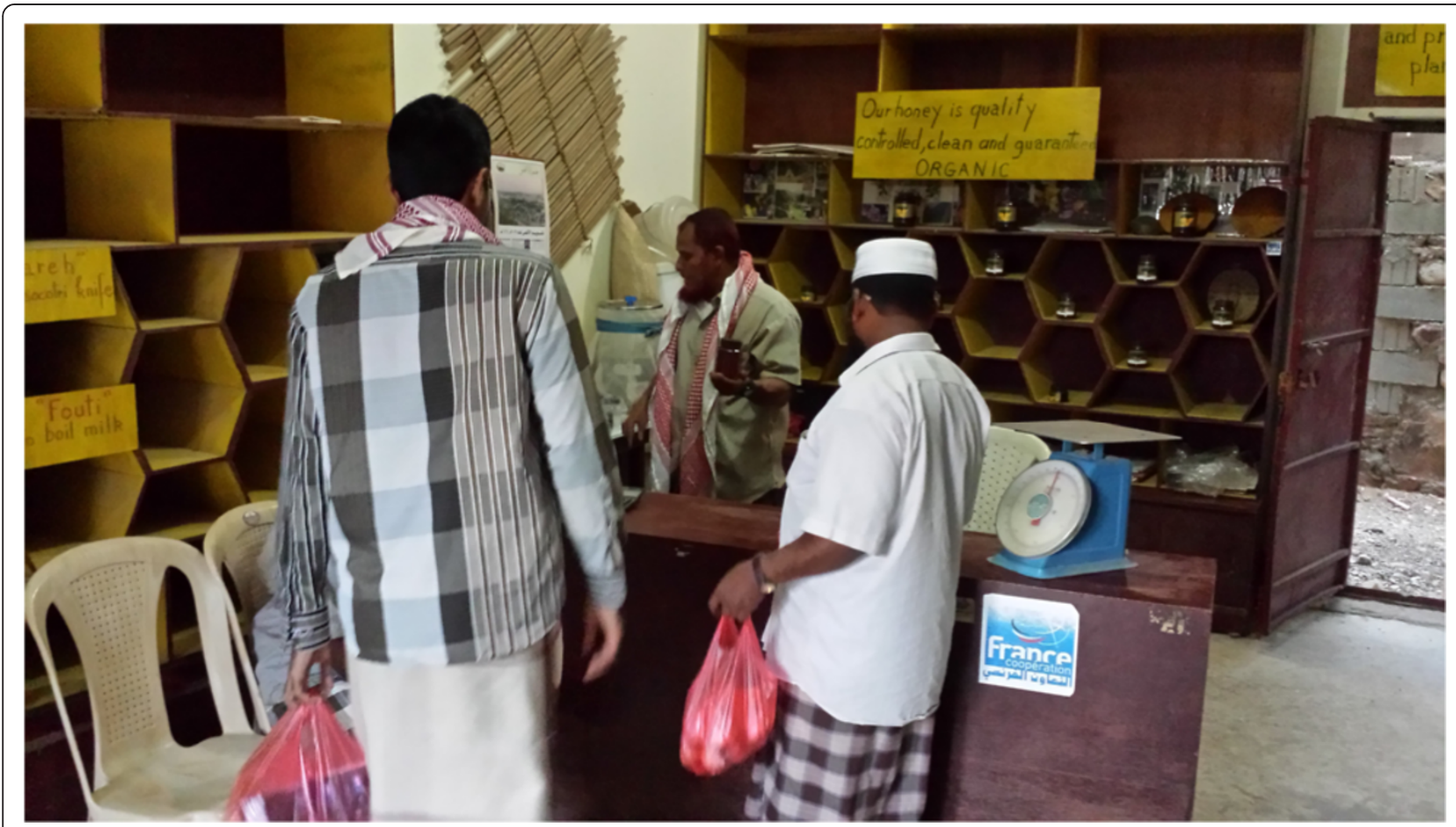

Figure 2 Honey shop in Hadiboh.

maximized' (EU 2000b: 2-10; Morris 2002:310). Pastoralism in Soqotra has persisted as a milk-subsistent livelihood. This is partly a legacy of the production of butter oil as export commodity, which was once a thriving cottage industry on the island. Soqotrans had developed a menu of dairy by-products, as the large quantity of available milk was transformed into, at least, seven milk by-products, as a means of preserving and extending consumption. The availability of the full range of milk by-products epitomized the Soqotrans' notion of bar$a k a$, as it symbolized nature's largess in terms of rain and pastures. Today, however, milk consumption is merely a seasonal delicacy, and the amount available allows, at the most, three dairy by-products. Nevertheless, meat production is not entirely neglected as it is pursued through the following practices: in the case of goats and sheep, young male stocks are reared for about 3 months for sale in the local market; mature female animals that have lost their breeding capacity are sold as well; in the case of cattle, some young males are reared for about 6 months or castrated and reared for 3 to 4 years for sale to the army base or for wedding ceremonies (EU 2000b).

The decline in the marketability of the pastoral economy's by-products, butter oil being the main one, and the non-development of livestock production for an external market was due to the nature of government economic policy. For example, the Socialist administration seemed to have regarded pastoralism as an economic dead-end as well as an obstacle to cultural emancipation, and thus was relatively neglected. This led to the abandonment of the production and export of butter oil. As a result, Soqotran pastoralists were transformed from primary producers into a seasonal proletariat dependent on foodstuff outside the pastoral domain. This shift in their status as producers contributed to their demise as full-time pastoralists, since they became both partly dependent on non-pastoral economic activities and entirely reliant on an imported food supply for their sustenance. On the other hand, the environmental vagaries have reduced their herds into a source of expenditure instead of income, since the animals have to be fed cereals, given the frequent unavailability of natural fodder. Consequently, pastoralism as a way of life has mutated almost entirely into an embodiment of a subsistence ethic and a repository of cultural symbolism. In such a context where pastoralism is economically moribund, but still culturally essential, the utility of the herd is conceived in two ways: first, as a source of seasonal food substitution, namely milk, which reduces dependence on some imported food items as well as minimizes the corollary cash expenditures, and second, it constitutes the main anchor to the land and provides the fundamental basis to the rationale about maintaining a way of life and preserving the means of socio-cultural reproduction. Moreover, this cultural preservation ethos regarding livestock is reified in a 
widespread sentimental reluctance among pastoralists to sell their animals. Indeed, the selling of animals is usually an act of last resort, when it is perceived as an economic imperative that must be submitted to. Consequently, Soqotran pastoralists betray an affective resistance towards the development of sustainable incomegenerating activities from their livestock. For them, the sale of animals is solely to meet basic needs, such as buying other food or medicine, and not to make money for its own sake.

Their socioculturally mediated production practices have settled into a set of deep-seated norms that have impeded the accumulation of a critical mass of livestock for an export market. Some of these norms that have impeded the productivity of Soqotra's pastoral economy include the following:

- The overwhelming majority of male kids are sold usually between 2 weeks and 3 months. This is partly because they do not produce, but consume, milk during that period, which makes them competitors with their herders for whom milk is an elixir of nature and the very raison d'etre of pastoralism in Soqotra. As one consultant report explains, 'The long period of milk consumption by the calf, kid or lamb explains why the pastoral people prefer to eliminate young males at an early age in order to minimize competition for milk preferred for human food' (EU 2000b). Hence, the sale of kids is more of a strategy of getting rid of food competitors than an income-generating one. It is as if male kids were a nuisance to the main objective of pastoralism: producing milk for human consumption. Accordingly, female goats are prized for their milk-producing ability and are rarely sold, except when they are no longer productive.

- The non-negotiable refusal by Soqotran pastoralists to ship their animals alive due to their obsessive concern about mistreatment during transport because it is thought that if the animals were mishandled during the transportation process, and later killed incorrectly, this would bring bad luck to the owner. ${ }^{a}$ Accordingly, they insist that the animals should be killed prior to shipment to an external destination.

- The increasing impatience of pastoralists regarding a long-term view of the pastoral economy - resulting from the corrosive conveniences of the modern economy - as attempts to persuade them to participate in the development of local nurseries of the local plant species to be used as fodder have not been successful, thus far. This is not only because these plants would take too long to become available for consumption but also more importantly the local availability of imported cereal that can be fed to the animals.

In addition to these 'cultural' obstacles, there is also a litany of misperceptions by potential external buyers: for example, animals from Soqotra are believed, falsely, to be fed with fish thus palatably unacceptable to mainland consumers; they do not have enough body fat and thus have no taste when cooked; animals are cheaper from Somalia and Ethiopia where they are shipped alive. These are complemented by the fact that all buyers prefer live animals, and thus are unwilling to buy dead animals from Soqotra. It is this combination of internal and external factors that have undermined Soqotran pastoralists' commitment to an income-generating pastoralism, instead of the current milk subsistence one. This disposition has created obstacles to the implementation of projects aimed at making pastoralism into an economically, or even commercially, viable source of livelihood. For example, the pastoralist project of the Soqotra Conservation Fund, 'Community-Based Livestock Development and Marketing Improvement' (2008-2011), which sought to initiate the commercialization of animal production in Soqotra, had to abandon its marketing objective. The project was unable to convince Soqotran pastoralists to compromise on their cultural prohibition against the sale of live animals. A local proverb, although expressed in Arabic, captures well the sentiment of Soqotran pastoralists regarding their herds, as it offers a moral injunction against using animals as commodities for sale: 'Don't consider her as your capital [source of financial gains] and don't send her away from your home' (lā tahsubhā rās mālak wa là taba'dahā 'an därak). The end result is that Soqotran pastoralists have obstinately refused to make the transition from considering their animals as a resource to be used only towards meeting their basic needs, to seeing them as a commodity to be sold for financial gains.

In the absence of a commercially viable livestock production system, Soqotran pastoralists have had recourse to a miscellany of odd jobs with which to 'patch-up' the deficiencies of the pastoral economy. Indeed, they did not have to wait for advice about economic diversification, as nature had already imposed it. This nature imposed diversification imperative has two dimensions: first, they have become opportunistic practitioners of a tri-modal livelihood system, as they shift from one to the other of the three traditional livelihoods (i.e., date farming, herding and fishing) according to their seasons' cycle, and they migrate to wherever access to these activities are possible, especially to the coastal zones for fishing, which is the most remunerative activity. Second, they participate in the constellation of activities related to construction: from the collection of the basic material rocks from the wadi, sand from the coast, gravel from the 
beach, soil wherever it is available - and transporting them to the construction site. However, they are usually employed as the unskilled labourers who carry the bricks and mortar. According to mainland contractors, they do not have the skills. This might be a convenient justification for not engaging in the transfer of skills, and thus avoiding the necessary mending of crosscultural barriers as well as the shedding of the mutually shared misanthropic perceptions.

\section{Distribution: self-delivery and provisioning}

Distribution refers to the gathering of locally produced goods and sending them to market for sale, or more generally to a dedicated place for economic transactions. There are two types of distribution mechanism: a marketplace, which is a physical location where goods are traded and a market system, that is the institutional organization of economic activities. Presently, there is nothing that resembles an organized market system in Soqotra as far as the sale of pastoral products is concerned. The non-availability of such a local market is due to two factors: first is the nature of production itself, which is for subsistence and thus there is a relatively meagre surplus to be distributed for sale, and second is that the conventional logic of supply and demand between producers in one sphere responding to consumers in another operates differently with Soqotran pastoralists: the supply of livestock is determined by the consumption needs of the producers (i.e., the pastoralists), and not the demands for meat from consumers in the urban centre. Accordingly, there is no weekly market for the sale of locally produced items, except for the irregular carload of goats and sheep brought to Hadiboh for sale by a muqāwil (contractor) who collects livestock from certain regions of the island (especially Momi in the east, Noged in the south and Diksam in the centre). However, there are two major occasions that provide the only sustained period for regular market transactions in livestock: first, the month of Ramadhan, as Muslims are required to be generous among themselves, and meat is an almost obligatory item on the menu after the fast and 'id al-ädhh $\bar{a}$ (Feast of Sacrifice), which takes place 3 months after the end of Ramadhan, which obliges the ritual of sacrificing an animal. Both these periods provide the most significant opportunity for market transactions in livestock (primarily goats and sheep, as cows are consumed during weddings and large invitations) and when distribution becomes less haphazard. These two occasions are the main ones during the year that pastoralists indulge in the sale of livestock for a little extra cash, not only to replenish their food quota but also to purchase new clothes as required by religious custom. There is a third factor, namely the season of sereb (October to February), which is the parturition season when there is a significant increase in the supply of animals for sale, as the pastoralists try to 'get rid' of their male kids. This seasonal 'glut' is combined with the demand generated by the high season for foreign and mainland tourists, as well as the visiting émigrés from the Gulf lead to increased meat consumption and thus distribution. During this season, the number of stalls and butchers increased as there are pick-up trucks almost daily bringing animals from the hinterland for sale in Hadiboh (Figure 3). With the exception of these three periods, the concept of a weekly market is applicable only to an imported product namely qāt, a mildly narcotic leaf that is chewed, which is flown in to Hadiboh from the mainland weekly and is the object of a lucrative activity for the sellers who are all from the mainland (see Elie 2014a). Finally, whatever organized distribution does exist, it does not involve local products but imported goods that are stocked in the honeycomb of shops scattered around the unpaved alleys that make up the marketplace in Hadiboh, which is the central economic hub of the entire island, with the other main town Qalansiyah a very insignificant second (see Elie 2004).

As in the case of production, the development of a local market in livestock is similarly constrained by certain practices regarding their sale, which include the following: (i) as already noted above, sale is unrelated to market demand, but to the subsistence needs of pastoralists who are primarily motivated by the need to replenish their limited basket of goods. (ii) It is contingent on the alternation between wet and dry seasons with different sale calculus for each, which is partly related to the limited size of herds: during the wet season, the focus is on selling only the male kids as milk production is at its peak, and during the dry season, the threat of the lack of natural fodder and thus preventing the death of the animals is the driving sale motive. (iii) The limited demand given the size of the potential market: six restaurants, one butcher stall shared by about four butchers that offer a relatively meagre supply that approximates a dozen goats a day, which reflects the equally meagre demand of local consumers. Using a back of the envelope calculation based on interviews with local butchers, the total number of animals (goats and sheep) sold at the only local meat market in Hadiboh on a weekly basis amounts to 100 heads per week or nearly 400 per month, each head averaging USD 25 (5,500 Yemeni Rial) for a monthly total of over USD 10,000. Even if the spike in consumption of meat that occurs during the observance of religious festivals (Ramadhan and the Feast of Sacrifice) is included the total sale of animals for an entire year may not exceed USD 150,000. The most frequent buyers of meat are the local residents from the mainland, and not Soqotrans, as they cannot afford it most of the time, and thus consume it infrequently, except during special 


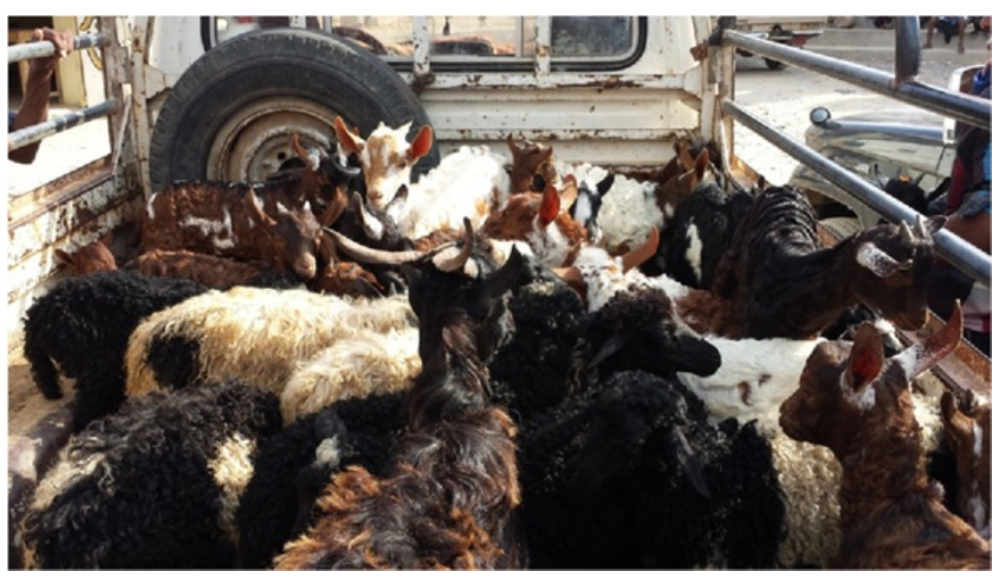

Figure 3 Goats and sheep in Hadiboh market (December 2013).

occasions, e.g., invitation of guests to celebrate major lifecycle rituals (birth, circumcision, marriage, death or returning émigrés), and religious holidays. However, the ability to buy meat in small portions from a butcher rather than having to kill or buy a whole animal has enabled the consumption of meat, as an occasional respite from fish, among the urban population. The two army bases on the island are potentially major markets for meat, but their procurement system seems haphazard, as it is guided by motive of convenience, and not local market expansion, as they import most of their food (Figure 4).

In the absence of these three seasonal factors - the high consumption season of sereb, Ramadhan and the 'id holidays - the normal means for the distribution of livestock for sale in its dominant manifestation on the island is the lone pastoralist either riding a taxi minivan from the rural areas carrying an animal or two, or trekking along steep mountain paths with one or two goats trailing him, and perhaps with his donkey on his way to Hadiboh to sell them. At destination, the pastoralist becomes an ambulant salesman going door to door to the local restaurants, or loiters around the butcher stall until he finds a buyer. The proceeds will be used to purchase the standard items (see list below) needed for a month or so, which either the donkey or public transport will take back to his village for a specific fee per item. Regarding the other auxiliary activities in the pastoral economy, date farming is exclusively for household consumption, and the harvest is unpredictable and usually insufficient for the year, and therefore, locally produced dates are not sold. In sum, the marketing of products from the pastoral economy is constrained by the subsistence motivation of the pastoralists and the local population's limited disposable income. Moreover, the limited supply of locally produced goods available for distribution is mirrored in the frugality of the consumption pattern of Soqotrans, both in the urban and rural areas, but especially in the latter, which is discussed in the next section.

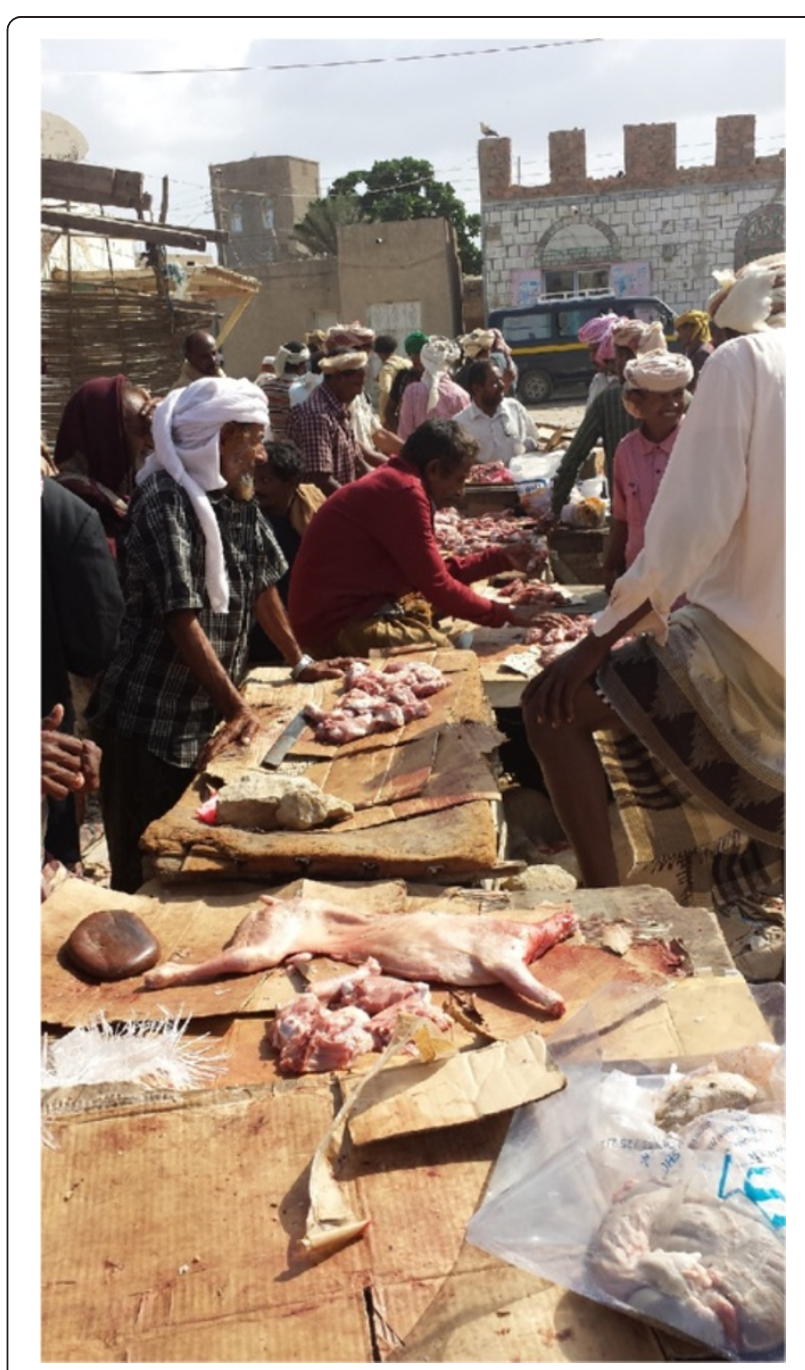

Figure 4 Meat market in Hadiboh town (December 2013). 


\section{Consumption: ascetic food substitution strategy}

The entire livelihood system of Soqotran pastoralists, or put differently their consumer attitude, is based on the suppression of the desire for consumption and the forced

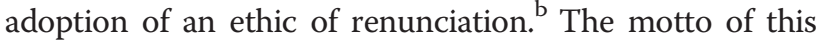
ethic can be formulated in a paraphrase of Gudeman's (1978:40) characterization of the consumption ethic of peasant farmers: self-maintenance over self-indulgence. That is, the conscious limitation of what is consumed to the most basic items, and the selection of which, is based primarily on their belly satiation value - indeed, on their hunger suppression value as in the case of tea, which is consumed continuously throughout the day. The basic items in the limited and standardized basket of goods are as follows: rice, flour, sugar, oil, tea, tomato paste, spices and powdered milk. In addition to this standardized list, there are variations according to agroecological zones: on the coast, fish and imported vegetables, fruits, poultry products among other items are available although infrequently consumed, since they are not always affordable and in the hinterland, milk seasonally and meat only occasionally, as the bedouin is most reluctant to deplete his herd capital; exception to the latter disposition being the male kid, which is usually sold within 3 months, or use to welcome a guest at lunch time. ${ }^{\mathrm{c}}$ The end result is that what people actually eat on the coast is rice supplemented with a fish sauce merely for taste as the quantity is minute compared with the number of mouths to feed, and in the hinterland rice with tomato paste or milk according to season. In the badiya, breakfast consists only of a few cups of tea, followed by rice for both lunch and dinner. In the urban areas, bread and tea with milk is served for breakfast and supper. Of course, consumption may vary depending on the financial capacity of individual consumers. In effect, this is a consumption substitution strategy that allows Soqotrans to adapt to a situation of a cashless economy in the hinterland since wealth is in the herd and not always willingly converted into cash, as discussed above, and given the chronic condition of insufficiency of disposable income in the coastal areas, due in part to the multiple needs of large families whose satisfaction is made possible only by the adoption of an ascetic consumption ethos, which is punctuated by the occasional slaughter of animals for a variety of social functions as noted above. Beyond this ethic of renunciation, there seems to be at work what Galaty and Johnson (1990) called an 'optimizing subsistence' strategy, which encompasses both production and consumption, and entails the following tactical manoeuvers: (a) meat consumption is sacrificed for the long-term availability of milk; (b) sale of animals is contingent on maintaining stability of herd size, if not marginally expanding herd growth; and (c) as noted above, recourse to the systematic culling (in the past) and sale (today) of male animals (especially goats and sheep) within 3 months of birth.

This circumstantially imposed ascetic ethos, or put differently, this chronic involuntary frugality, seems to have induced a levelling of expectations, as if a form of social resignation has set in, induced by the inability to envision a way out of the eternal pendulum swing from a hand to mouth existence in the pastoral hinterland. There is a recognition of living under conditions of relative deprivation, but it has not mutated into a self-awareness of poverty as a defining self-concept. However, with the increasing monetization of the economy, and the resulting socio-economic differentiation within the population, poverty may well become a self-defining notion. Indeed, by established standards of poverty, Soqotran pastoralists emblematize socio-economic deprivation. Yet they are not begging in the streets of Hadiboh. In this regard, Sahlins' observation seems pertinent to the Soqotran situation: they may 'have few possessions, but they are not poor. Poverty is not a certain small amount of goods, nor is it just a relation between means and ends; above all it is a relation between people. Poverty is a social status' (quoted in Fried 1975: 44). This is echoed in Botting's remark that 'On the island where almost everybody is poor, and there are as yet no foreign standards to shame and disturb them, poverty is accepted without degradation' (Botting 1958: 77). It is perhaps a blessing in disguise that the UN interventions on the island have been under the banner of environmental protection and biodiversity conservation and not under that of poverty alleviation, which could have suggested itself as the 'paradigm of self-definition'. The latter would have engendered the construction of underdeveloped subjectivities among Soqotrans, as they sought to accommodate themselves to the signifiers of poverty and the accompanying plethora of deficiencies that such a paradigm privileges in its discourse, in order to obtain assistance from UN projects. This would have generated an incentive among Soqotrans to appropriate poverty as a selfdefining concept, which, in turn, would have entailed a communal submission to an 'abstract universal measure of underconsumption' (Illich 1992:94).

However, while poverty as a self-defining concept may not have achieved paradigmatic status, it is the defining characteristic of the population with $49 \%$ under the poverty line. And the iron grip of the subsistence ethic and its ascetic consumption pattern has reinforced the symbiotic linkage between low productivity and low consumption, especially in the pastoral hinterland. This in turn has undermined the formation of an awareness, or more aptly of a sensibility, that allows for an appreciation of alternative economic possibilities that might require a different 'effort quotient': that is, the equation between delayed gratification and exertion of effort associated 
with the pastoralist livelihood. The end result is an increasing unwillingness to endure delayed gratification outside the pastoral domain, and the adoption of a value system characterized by a premature desire for instantaneous pecuniary gratification. What this seems to indicate is an unwillingness to transfer the high effort quotient associated with traditional sector activities to the nontraditional sector. For example, the difficulty of agriculture to find an economic niche on the island seems to be related to its absence of instantaneous pecuniary gratification, as agriculture involves hard labour and the result of which must wait a few months, while in fishing, the benefits are nearly instantaneous. Accordingly, men in general have been disinclined to engage in agricultural activities unrelated to date farming because, they say, there is no money in it. Indeed, the economic potential of agriculture remains limited given that less than $1.5 \%$ of the island's total surface is arable land, which is equivalent to only $380 \mathrm{~km}^{2}$. Today, agriculture remains a predominantly, if not exclusively, women activity, although men participate in selling agricultural produce.

The economic behaviour of the Soqotran pastoralists presents a certain paradox, as it is not clear whether their needs and desires are being limited consciously in order to minimize their level of effort, according to locally established norms of sufficiency, or whether they have yet to find new needs and desires outside the traditional sector that would compel greater effort. This point finds resonance in Ellen's discussion of the symbiosis between level of effort, subsistence techniques and consumption needs, as she explains, 'people generally choose the techniques which yield a given return with minimum effort rather than the maximum yield for a given outlay of effort, unless they are under great nutritional stress' (Ellen 1994: 219). In spite of the expenses incurred in maintaining their herds - both in terms of cash expenditures on purchasing cereals to feed them given the chronic insufficiency of natural fodder, and in terms of the daily inconveniences such as organizing one's day around their needs, and with minimal or no economic benefits - the Soqotran pastoralists continue to hold on to this livelihood practice as a defining cultural leitmotif. This pastoral ethos is still engrossed in a sensibility honed in a waning era, during which prevailed a 'moral community of subsistence' practicing an inadvertently ecologically sustainable mode of coping with nature's vagaries, and for which the initial conditions for its sustainability are gradually disappearing.

\section{Conclusion: future scenarios}

In Soqotra's pastoral economy, livestock seem to have a culturally assigned path within the spectrum of production, distribution and consumption, in which they enter the exchange path based on specific conditions. In effect, Soqotra's pastoral economy constitutes a 'restricted system of commodity [i.e., livestock] flow' (cf. Appadurai 1986). Animals enter the commodity stream only contingently, such as (a) weather and season; (b) the herder's consumption needs, medical emergency, etc.; and (c) the availability of alternative means of satisfying these needs without resorting to the sale of animals. Accordingly, herds are subject to a restricted circulation - or stated differently, enter the distribution circuit to be sold - in a manner that is evocative of a barter mode of exchange, in which money is merely a 'measure of equivalence' based on the value of the goods to be acquired after the animal is exchanged: animal $\{$ money $\}=$ food basket (cf. Appadurai 1986). Perhaps, this sums up the Soqotran pastoralists' economic rationality. Indeed, from the discussion in the previous section, it seems that the future of pastoralism in Soqotra does not include a shift from a subsistence emphasis of an extensive pastoralism to an exchange mode through the intensification of livestock production and its commercialization. Instead, the future of pastoralism may lie in a continuation of the ethic of 'patching-up' through the opportunistic diversification of sources of income generation outside the pastoral economy. In effect, the resilience of Soqotra's pastoralism, thus far, is not due to its practitioners' political resistance to the state in order to defend an identity, but a strategic participation in its dominant political economy to ensure the sustainability of a communal mode of livelihood.

While Soqotran pastoralists in the hinterland are still attached to the ascetic ethos of self-maintenance as opposed to the consumerist ethic of self-indulgence, they are not impervious to change. Indeed, the above discussion has shown their adaptability to different politicaleconomic regimes. However, the current conservationist regime encompassing Soqotra's pastoral economy is excessively proscriptive regarding Soqotrans' traditional socio-ecological practices (for details, see Elie 2014b). This conservationist political economy is embedded within a transnational eco-fundamentalist vision, which seeks to preserve the entire island as an Arcadian bioregional enclave. Indeed, this vision seems animated by a 'graze phobia' that reinforces the false 'public image of extensive rangelands are of pasture land overgrazed by livestock, and therefore in environmental crisis, and threatening wildlife and biodiversity' (Niamir-Fuller et al. 2012:2).

Accordingly, the ascribed agency of Soqotran pastoralists is as national park custodians to protect the genetic heritage of humankind, while their contemporary aspirations are being neglected. In this vision, 'development' is conceived as a moral and philanthropic quest led by external actors and agencies to enhance the quality of life of a community within a pre-modern social context. This vision - as expressed in the European Commission funded Soqotra Archipelago Master Plan, the blueprint for a new eco-centric economy in Soqotra - is devoid of 
any socially transformational objective: 'Development... is to support the traditional land/marine practices of aeons... [through] the identification of areas where current good practices can be enhanced and stabilized, and made more rewarding... without detracting from their [traditional] lifestyle' (EU 2000a 5:4). Ultimately, the aim of this 'development' is not emancipation from local conditions of relative socio-economic deprivation, but adjustment to it through a series of palliative microscale interventions (see Elie 2006: chapter 7). This ecocentric vision of the island is threatening the continued participation, at least of the new generation, of Soqotrans in their 'traditional cultural commons', thereby impeding the renewal of the carriers of the island's pastoral way of life (cf. Narotzky 1996: 169-89).

These events are challenging not only the 'resilience quotient' of Soqotran pastoralism as a mode of livelihood but also the cultural viability of the rural community of pastoralists. This is manifested in an emerging imbalance between (a) the declining adaptive and reproductive capacity based on a viable knowledge repertoire and a functioning intergenerational transfer mechanism, and (b) increasing vulnerability due to the chronic deficit of environmental resources. These factors are further exacerbated by the socio-economic discontinuities caused by the modernization initiatives of the state such as the introduction of formal schooling in a nonindigenous language, and in the economic realm through the creation of new remunerative opportunities in nontraditional occupations. These factors are disrupting pastoralism's adaptive and reproductive capacity by undermining the socio-economic incentives that sustain the transfer of local pastoral knowledge, and thus inducing a new generation of rural residents to shift out of pastoralism.

The end result is a generational gap, resulting in a divergence of sociocultural attitudes and occupational preferences between an older and younger generation, that threatens the sustainability of the pastoral livelihood. Consequently, Soqotran pastoralists are caught between a rural economy that straddles a transitional threshold, and an experimental state-sponsored and internationallysupported eco-centric economy that is unwittingly encouraging cultural defection among rural residents away from their traditional livelihood practices with promises of new economic opportunities, while being unable to ensure the availability or sustainability of the occupational alternatives. As a result, the pastoral economy is in a state of indeterminacy, and the optimum path forward is not clear. In this light, what are the likely future paths of pastoralism in Soqotra? Three paths are briefly considered below:

- From subsistence to commercial herding. This is the Somalia model, where pastoralism was transformed from its former subsistence orientation to one of commercial production for export markets in Saudi
Arabia, and Yemen, among other places; however, with relatively little change in production techniques (i.e., the traditional practice of extensive herding was never replaced by intensive ranching). ${ }^{\mathrm{d}}$ Presently, given the nature of the economic rationality that has sedimented in the production and distribution practices of Soqotran pastoralists, as discussed above, the window of opportunity for such a transition seems to be permanently closed.

- Small-scale ranching. This is the approach envisioned by the national and foreign planners of the conservationist regime. It entails the selective modernization of pastoralism through the social engineering of a geographically demarcated transition from subsistence milk pastoralism to an investmentbased ranching. The targeted domains of intervention are the World Heritage sites and other protected areas where pastoralists will be moved out to designated areas as ecologically friendly small-scale ranchers, and where they will occasionally become ecotourism entrepreneurs targeting foreign visitors, while performing their ascribed role as national park custodians. However, because of the 'cultural obstacles' discussed above, this ranching strategy may find few takers and is thus unlikely to ever be implemented.

- Diversification. This is the current spontaneous orientation of Soqotran pastoralists as practitioners of the 'patching-up' ethic, which privileges a strategy of diversification over intensification. This strategy entails the straddling of the hinterland subsistence economy and the urban-based modern economy through working as full- or part-time participants in non-traditional jobs with a regular salary that is not contingent on the seasons. The cash earned in the modern economic sector is ploughed back into the pastoral domain, which they do not intend to abandon - while not expecting it to provide more than a subsistence income either. The motivation is to preserve their herds, to satisfy their passion for milk, and to secure their individual or collective claim over their territorial domain in the hinterland.

The chronic attention span deficit of the Yemeni state with regards to Soqotra, the lack of local support for the imported templates, and externally imposed priorities of the conservationist political economy enveloping the island, combined with the erratic funding for its implementation will ensure, for the foreseeable future, the continuing practice by Soqotran pastoralists of the 'patching-up' ethic of their auxiliary livelihood.

\section{Endnotes}

${ }^{a}$ The sensitivity of Soqotrans towards the state and fate of their animals is rather excessive. For example, if an 
animal (e.g., a goat) dies due to the negligence of its pastoralist owner, he is obligated to perform the penitential ritual of sha'feroh (from eastern/central Soqotra or shaghfereh from western Soqotra), which is equivalent to the Islamic ritual of repentance, kaffära: to ask God for forgiveness after violating an oath or committing a wrong. This ritual calls for the sacrifice at least seven goats, as a means of expiation for his cruelty - however involuntary - towards his herd. This number of goats represents an onerous compensation that is meant to warn the pastoralist from negligent behaviour towards his animals. This ritual perhaps explains Soqotran pastoralists' reluctance to export their animals alive.

${ }^{\mathrm{b}}$ Botting confirms the longevity of this disposition when he observed that 'The people seem to get along on remarkably little food... I would never say that any of them looked undernourished and yet their diet seems to consist of dates and milk during the day and meqaderih [maize] at night. Occasionally a goat is slaughtered, but only for the chosen few' (Botting 1958: 203). However, this ethic of renunciation or ascetic ethos was occasionally punctuated in the past as well as today by the ritual slaughter of animals for a number of social functions: the culling of male kids as a herd management strategy and their consumption (today they are sold), weddings and funerals (where some half of the dead person's animals were slaughtered) where all could come and eat and many travelled miles to do so, circumcision ceremonies, slaughter after a woman has given birth, co-operative labour (girif) for which the one gaining benefit had to give his co-workers meat, clan gatherings etc. (personal communication with Dr. Miranda Morris).

${ }^{\mathrm{c}}$ In this connection, one could reasonably suppose that in the course of a year, more animals are consumed through invitations for guests and wedding ceremonies than is sold in the market outlets mentioned above. This is especially so, given the rufda custom, which is practiced in the badiya, and is the collective giving of gifts of livestock to the groom by all the neighbouring clans in the area where the wedding is to take place. This custom is a form of competition between clans as to which one would be the most generous in their offerings. It is an act of generous solidarity that is embedded in a system of reciprocal gift giving during the major life-cycle events: birth, marriage and death.

${ }^{\mathrm{d}} \mathrm{A}$ parenthetical comparative historical note is instructive in terms of the relationship between the state's political economy and the community's subsistence economy: it is worth noting that it was the presence of the British in Aden that provided the catalyst to Somalia's commercialization of livestock export to South Arabia (Swift 1979). In Soqotra, where the British were the overseers of the Sultanate there was never any attempted transition from butter oil production to export of livestock.
While the island's topographic and territorial constraints may have presented obstacles to such a transition, the British non-development policy towards the island may have been more decisive.

\section{Competing interests}

The author declares that he has no competing interests.

\section{Author's information}

SDE has a D.Phil. in social anthropology from the University of Sussex, UK $\mathrm{He}$ is a former international development professional at United Nations Development Programme. He is currently a Research Associate at the Yemen Center for Studies and Research in Sanaa. He has published in over 20 academic journals. His research area is state-society relations in the Middle East/West Asia. He is completing a book manuscript on the historical process and contemporary ramifications of the Yemeni state's politics of incorporation of a sub-national communal formation.

\section{Acknowledgements}

The author acknowledges the valuable suggestions of the anonymous reviewers of the Pastoralism journal and the helpful comments of the journal editor, Carol Kerven. Also, a special thanks to Dr. Miranda Morris for her informational input to the manuscript.

Received: 13 March 2014 Accepted: 8 September 2014

Published online: 08 October 2014

\section{References}

Appadurai, A. 1986. Introduction: Commodities and the politics of value. In The social life of things: Commodities in cultural perspective, ed. A Appadurai, 3-63. Cambridge: Cambridge University Press.

Botting, D. 1958. Island of the Dragon's Blood. London: Hodder \& Stoughton.

Ceccolini, L. 2002. The homegardens of Soqotra Island, Yemen: An example of agroforestry approach to multiple land-use in an isolated location. Agroforestry Systems 56:102-115.

Chatty, D (ed.). 2006. Nomadic societies in the Middle East and North Africa: Facing the $21^{\text {st }}$ century. Leiden: Brill.

Commission of the European Communities (EU). 2000a. Soqotra archipelago master plan. MoPD: Sana'a.

Commission of the European Communities (EU). 2000b. Sectoral report: Agriculture and livestock. MoPD: Sana'a.

Doe, B. 1992. Socotra: Island of Tranquility. London: IMMEL Publishing

Earle, T. 2002. Commodity flows and the evolution of complex societies. In Theory of economic anthropology, ed. J Ensminger, 81-104. New York: Altamira Press.

Elie, SD. 2004. Hadiboh: From peripheral village to emerging city. Chroniques Yémenites 12:53-81.

Elie, SD. 2006. The waning of a pastoralist community: An ethnographic exploration of Soqotra as a transitional social formation. D.Phil. dissertation. UK: University of Sussex.

Elie, SD. 2008. The waning of Soqotra's pastoral community: Political incorporation as social transformation. Human Organization 67(8):335-345.

Elie, SD. 2009. State-community relations in Yemen: Soqotra's historical formation as a sub-national polity. History and Anthropology 20:363-393.

Elie, SD. 2014a. Qät consumption in Soqotra: Diaspora formation and cultural conversion. Northeast African Studies 14(1):1-42.

Elie, SD. 2014b. Pastoralism in Soqotra: External entanglements and communal mutations. Pastoralism: Research, Policy and Practice

Ellen, R. 1994. Modes of subsistence: Hunting and gathering to agriculture and pastoralism. In Companion encyclopedia of anthropology: Humanity, culture and social life, ed. T Ingold, 197-225. New York: Routledge.

Fried, M. 1975. The notion of tribe. California: Cummings Publishing Company

Galaty, JG, and DL Johnson (eds.). 1990. The world of pastoralism: Herding systems in comparative perspective. New York: Guilford Press.

Galvin, KA. 2009. Transitions: Pastoralists living with change. Annual Review of Anthropology 38:185-198.

Gorz, A. 1993. Political ecology: Expertocracy versus self-limitation. New Left Review 202:55-67.

Gudeman, S. 1978. The demise of a rural economy: From subsistence to capitalism in a Latin American village. London: Routledge \& Keegan Paul. 
Gudeman, S. 2001. The anthropology of economy: Community, market, and culture. Oxford: Blackwell.

Heatherington, T. 2001. Ecology, alterity and resistance in Sardinia. Social Anthropology 9(3):289-306.

Illich, I. 1992. Needs. In The development dictionary: A guide to knowledge as power, ed. W Sachs, 88-101. London: Zed Books.

Khazanov, AM. 1994. Nomads and the outside world, 2nd ed. Madison: University of Wisconsin Press.

Miller, A, and M Morris. 2004. Ethnoflora of the Soqotra archipelago. Edinburgh: Edinburgh University Press.

Morris, M. 2002. Soqotra archipelago: Manual of traditional land-use practices. Edinburgh: Royal Botanic Garden.

Narotzky, S. 1996. New directions in economic anthropology. London: Pluto Press.

Niamir-Fuller, M, C Kerven, R Reid, and E Milner-Gulland. 2012. Co-existence of wildlife and pastoralism on extensive rangelands: Competition or compatibility. Pastoralism: Research, Policy and Practice 2(8):1-14.

Scholte, P, and P De Geest. 2010. The climate of Socotra Island (Yemen): A first-time assessment of the timing of the monsoon wind reversal and its influence on precipitation and vegetation patterns. Journal of Arid Environments 74:1507-1515.

Swift, J. 1979. The development of livestock trading in nomad pastoral economy: The Somali case. In Pastoral production and society, Equipe ecologie and Anthropologie des Sociétés Pastorales, 447-466. Cambridge: Cambridge University Press.

doi:10.1186/s13570-014-0015-4

Cite this article as: Elie: Soqotra's pastoral economy: from core to auxiliary livelihood. Pastoralism: Research, Policy and Practice 2014 4:15.

\section{Submit your manuscript to a SpringerOpen ${ }^{\circ}$ journal and benefit from:}

- Convenient online submission

- Rigorous peer review

- Immediate publication on acceptance

- Open access: articles freely available online

- High visibility within the field

- Retaining the copyright to your article

Submit your next manuscript at $>$ springeropen.com 